Development of a modified transformation platform for apomixis candidate genes research in Paspalum notatum (bahiagrass)

Micaela Mancini, Nadia Woitovich, Hugo R. Permingeat, Maricel Podio, Lorena A. Siena, Juan Pablo A. Ortiz, Silvina C. Pessino, et al.

In Vitro Cellular \& Developmental Biology - Plant

ISSN 1054-5476

In Vitro Cell.Dev.Biol.-Plant DOI 10.1007/s11627-014-9596-2

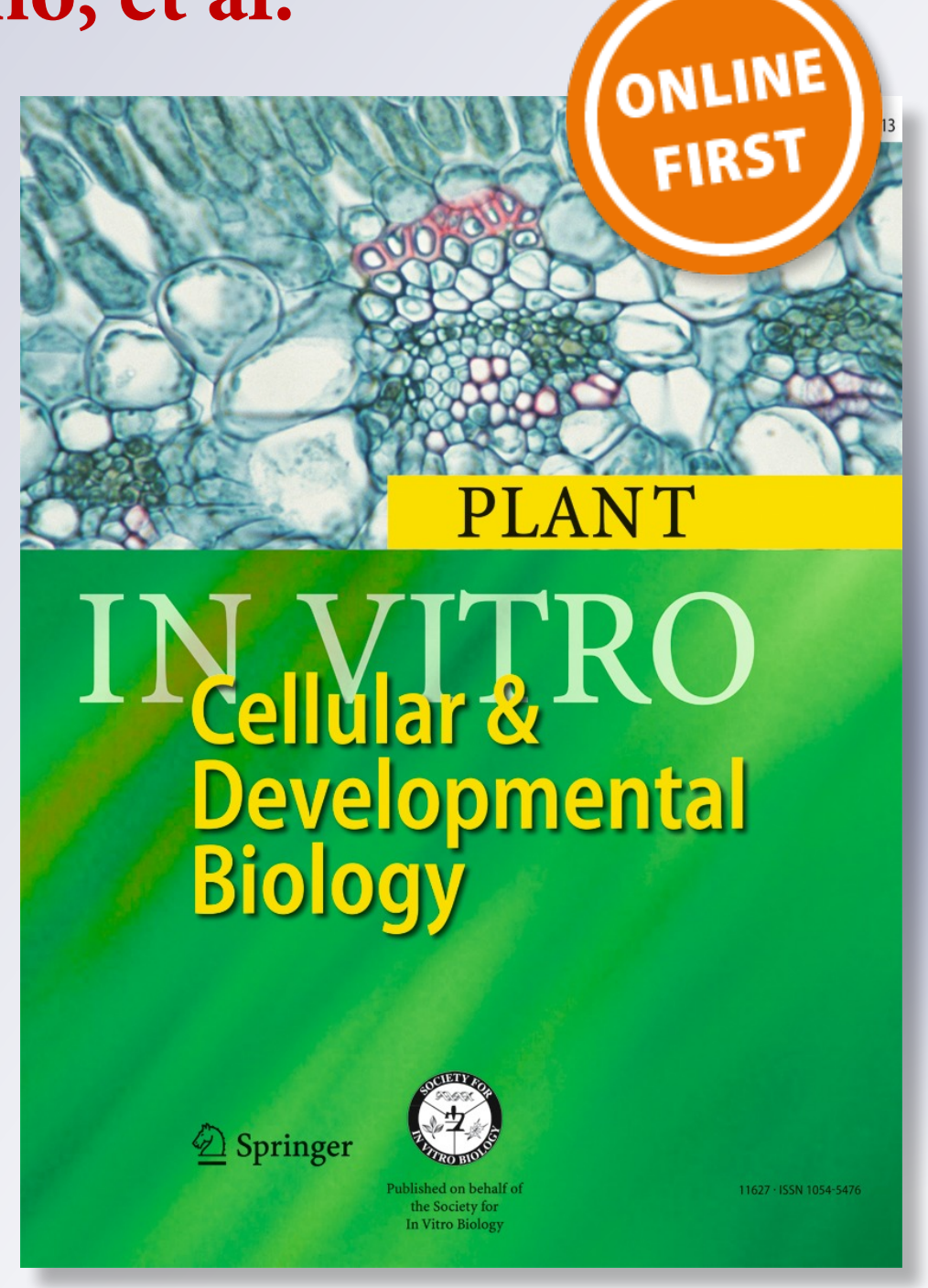

脰 Springer 
Your article is protected by copyright and all rights are held exclusively by The Society for In Vitro Biology. This e-offprint is for personal use only and shall not be selfarchived in electronic repositories. If you wish to self-archive your article, please use the accepted manuscript version for posting on your own website. You may further deposit the accepted manuscript version in any repository, provided it is only made publicly available 12 months after official publication or later and provided acknowledgement is given to the original source of publication and a link is inserted to the published article on Springer's website. The link must be accompanied by the following text: "The final publication is available at link.springer.com". 


\title{
Development of a modified transformation platform for apomixis candidate genes research in Paspalum notatum (bahiagrass)
}

\author{
Micaela Mancini • Nadia Woitovich • \\ Hugo R. Permingeat • Maricel Podio • Lorena A. Siena • \\ Juan Pablo A. Ortiz • Silvina C. Pessino • Silvina A. Felitti
}

Received: 1 October 2013 / Accepted: 13 January 2014 / Editor: J. Forster

(C) The Society for In Vitro Biology 2014

\begin{abstract}
The aim of this work was to improve existing transformation protocols and to transform specific genotypes of Paspalum notatum (bahiagrass) for functional analyses of candidate genes involved in reproduction. Three different explants were assayed for in vitro plant regeneration: mature seeds, mature embryos, and shoot meristems. Plant regeneration was achieved with all explant types, but mature seeds produced the optimal rate (78.0\%) and were easiest to manipulate. A method based on serial re-induction of calli from meristems of the regenerated lines was also developed, which could be useful in plant breeding strategies pursuing somaclonal variation. Transient transformation experiments were performed on calli obtained from mature seeds using a compressed helium gene gun. Transient transformation constructs included anthocyanin-synthesis genes cloned under the CAMV 35S promoter and an enhanced green fluorescent protein gene (egfp) driven by the rice actin1 (act1) promoter. Selection curves for ammonium glufosinate were developed in order to determine the optimal selective pressure for stable transformation $(1.0 \mathrm{mg} / \mathrm{L})$. Stable co-transformation experiments were carried out with two different constructs containing: (1) the reporter egfp gene cloned under the rice act1 promoter and (2) the selector bar gene driven by the ubiquitin promoter. A total of 27 (64.2\%) transgenic plants out of 42 resistant plants analyzed were obtained. The presence of the transgenes in regenerated plants was confirmed by
\end{abstract}

\footnotetext{
M. Mancini $\cdot$ N. Woitovich $\cdot$ H. R. Permingeat $\cdot$ M. Podio $\cdot$

L. A. Siena $\cdot$ J. P. A. Ortiz $\cdot$ S. C. Pessino $\cdot$ S. A. Felitti $(\bowtie)$

Laboratorio de Biología Molecular, Facultad de Ciencias Agrarias,

Universidad Nacional de Rosario, Parque Villarino,

S2125ZAA Zavalla, Provincia de Santa Fe, Argentina

e-mail: sfelitti@unr.edu.ar

M. Podio · J. P. A. Ortiz

Instituto de Botánica del Nordeste (IBONE), CONICET, Facultad de Ciencias Agrarias, Universidad Nacional del Nordeste, Sargento

Cabral 2131, W3402BKG Corrientes, Argentina
}

polymerase chain reaction and DNA gel blot analysis. Gene expression was demonstrated by eGFP fluorescence detection and in vivo assays for ammonium glufosinate tolerance. This platform is being used to generate transgenic plants of $P$. notatum to analyze the function of apomixis-associated candidate genes.

Keywords Biolistic transformation P Paspalum notatum . Ammonium glufosinate $\cdot E g f p \cdot$ Apomixis

\section{Introduction}

Apomixis is a genetically determined type of asexual reproduction in angiosperms that results in the production of viable seed from maternal tissues in the absence of meiosis and fertilization (Nogler 1984). The offspring originating from apomixis are exact genetic replicas of the mother plants. This trait is perceived as an important potential tool for plant breeding, since its manipulation would enable preservation of hybrid vigor and simplify plant breeding methods and wide-crossing (Spillane et al. 2004). Apomixis, however, is absent from major crops. To date, plant genetic transformation has not been explored as a tool to facilitate harnessing apomixis for the benefit of agriculture. While in the past few years dozens of genes differentially expressed during sexual and apomictic development (Leblanc et al. 1997; Chen et al. 1999; Albertini et al. 2004; Cervigni et al. 2008; Laspina et al. 2008) or positionally linked to apomixis (Calderini et al. 2006; Conner et al. 2008; Podio et al. 2012) have been identified, functional studies have been performed only on randomly generated mutants originated from model sexual species.

Our research team identified 65 candidate genes differentially expressed in the reproductive tissues of sexual and apomictic Paspalum notatum (Laspina et al. 2008). Therefore, we are interested in developing an efficient transformation 
protocol for introducing candidate genes in specific obligate apomictic or fully sexual tetraploid $P$. notatum genotypes to analyze the derived phenotypes.

Some useful in vitro culture and biolistic transformation protocols have already been developed for P. notatum. Bovo and Mroginski (1989) regenerated plants from tetraploid mature embryos. Marousky and West (1990) used mature caryopses as explants, whereas Shatters et al. (1994) employed leaf-stem cross-sections to initiate the plant regeneration process. Grando et al. (2002) used seeds from diploid P. notatum as explants, optimized the production of embryogenic calli and showed they were amenable to transient transformation. Altpeter and Positano (2005) developed an efficient protocol for the regeneration of tetraploid bahiagrass plants from callus using mature seed explants. Smith et al. (2002) obtained tetraploid transgenic plants resistant to glufosinate, and Gondo et al. (2005) produced bialaphos-resistant diploid plants through callus bombardment. Altpeter and James (2005) used biolistic gene transfer into embryogenic callus derived from mature seeds to obtain paromomycin-resistant apomictic bahiagrass. Altpeter's group utilized this protocol to produce transgenic plants displaying reduced levels of endogenous gibberellins (Agharkar et al. 2007), and to study bar transgene expression in apomictic progeny of bahiagrass (Sandhu et al. 2007). In addition, the expression of Arabidopsis ATHB16 (Zhang et al. 2007) and wild barley HsDREB1A (James et al. 2008) transcription factors in bahiagrass originated changes in plant architecture and abiotic stress tolerance, respectively. Sandhu and Altpeter (2008) used two minimal transgene expression constructs and evaluated co-integration, quantified coexpression, and analyzed inheritance to apomictic seed progeny. More recently, Xiong et al. (2009) obtained drought tolerant plants by over-expressing the barley WRKY 38 transcription factor. All these studies were conducted on the apomictic, tetraploid cultivar 'Argentine' aiming at the molecular improvement of turf quality.

We considered all of these previously developed methodologies as valuable starting points and analyzed several independent protocols, examining alternative explants and conditions, to design a platform best suited to a wide range of genotypes. Genetic improvement of tetraploid P. notatum cultivars has been compromised by the absence of genetic recombination in natural apomictic genotypes. Genetic manipulation through cellular and molecular techniques may overcome this difficulty. The aim of this work was to improve on existing transformation protocols and to transform specific genotypes of $P$. notatum for gene functional analyses. Moreover, we developed a serial meristem-based in vitro culture approach, derived from the protocol reported by Bajaj et al. (2006), consisting of two successive rounds of embryogenic calli induction from meristematic tissues, which possibly leads to an accumulation of mutations. This novel strategy could be implemented for in vitro culture-based plant breeding programs of apomictic grasses that ultimately seek the occurrence of somaclonal variation to generate novel genotypes. The tools developed here will be useful for apomixis research and breeding of clonally reproducing grasses.

\section{Materials and Methods}

Plant material. Experiments were conducted using P. notatum seeds obtained from: (1) the pseudogamous self-fertile tetraploid apomictic plant Q4117 $(2 n=4 x=40)$ and (2) the completely sexual Q4188 $(2 n=4 x=40)$ genotype, which was used as female parent in crosses to sexual JS-83 $(2 n=4 x=40)$.

Q4117 is an obligate apomictic tetraploid clone collected from a natural population in southern Brazil (Ortiz et al. 1997). Q4188 is a hybrid derived from the cross between Q3664 and the natural apomict Q3853 (Quarin et al. 2003). JS-83 is an $\mathrm{F}_{1}$ progeny obtained by crossing Q4188 as the female parent with Q4117 as a pollen donor (Stein et al. 2007).

In vitro culture media. The media used in in vitro culture experiments are listed in Table 1. All media contained $4.3 \mathrm{~g} /$ $\mathrm{L}$ MS salts and B5 vitamins, $30 \mathrm{~g} / \mathrm{L}$ sucrose, $2.2 \mathrm{~g} / \mathrm{L}$ Phytagel $^{\mathrm{TM}}$, and $100 \mu \mathrm{L} / \mathrm{L}$ preservative solution $(20 \%[v / v]$ Kathon CG [Sigma-Aldrich, Buchs, Switzerland], $140 \mathrm{mM}$ potassium sorbate, and $140 \mathrm{mM}$ sodium benzoate) to prevent contamination (Guri et al. 1998). Prior to solidification, the $\mathrm{pH}$ was adjusted to 5.7 with $1 \mathrm{~N} \mathrm{NaOH}$. Media were autoclaved for $30 \mathrm{~min}$ at $120^{\circ} \mathrm{C}$ and $150 \mathrm{kPa}$. Plant growth regulators (PGRs) and vitamins were sterilized using $0.2-\mu \mathrm{m}$ filters (Millipore, Billerica, MA) and added to temperate sterilized media.

Plant regeneration. The methodology used was based on protocols reported by Grando et al. (2002), Smith et al. (2002), and Gondo et al. (2005), with some modifications. Briefly, mature seeds originating from Q4117 (apomictic) or the cross Q4188 $\times \mathrm{JS}-83$ (sexual) were incubated at $28^{\circ} \mathrm{C}$ for $48 \mathrm{~h}$. Then, they were treated with concentrated $\mathrm{H}_{2} \mathrm{SO}_{4}$ for $30 \mathrm{~min}$, for dehusking and dormancy breaking. The seeds were surface-sterilized with commercial bleach containing $50 \%(v / v) \mathrm{NaClO}\left(35 \mathrm{~g} / \mathrm{L}\right.$ active chlorine) and $100 \mu \mathrm{LTween}^{\circledR}$ 20 for $7 \mathrm{~min}$, followed by a treatment with $97 \%(v / v)$ ethanol for $7 \mathrm{~min}$. Finally, the seeds were washed three times with sterile distilled water and blotted dry on sterile filter paper.

For the mature seed-based regeneration protocol, approximately $15-30$ seeds were placed in each Petri dish containing MM5 medium (Table 1) and cultured in the dark at $28^{\circ} \mathrm{C}$ for approximately $10 \mathrm{~d}$. Each experiment carried out with seeds originating from plant Q4117 involved 12 plates and was repeated ten times (comprising a total of 120 plates). Each experiment carried out with seeds originated from the cross 
Table 1. Composition of in vitro culture media

\begin{tabular}{|c|c|c|c|c|c|c|c|c|c|c|}
\hline Name & $\begin{array}{l}\text { MS salts }+\mathrm{B} 5 \\
\text { vitamins }(\mathrm{g} / \mathrm{L})^{\mathrm{a}}\end{array}$ & $\begin{array}{l}\text { Sucrose } \\
(\mathrm{g} / \mathrm{L})\end{array}$ & $\begin{array}{l}\text { SH salts } \\
(\mathrm{g} / \mathrm{L})^{\mathrm{b}}\end{array}$ & $\begin{array}{l}\text { BAP } \\
(\mu \mathrm{M})\end{array}$ & $\begin{array}{l}\text { Dicamba } \\
(\mu \mathrm{M})\end{array}$ & $\begin{array}{l}2,4-\mathrm{D} \\
(\mathrm{mg} / \mathrm{L})\end{array}$ & $\begin{array}{l}\mathrm{GA}_{3} \\
(\mu \mathrm{M})\end{array}$ & $\begin{array}{l}\mathrm{CuSO}_{4} \\
(\mu \mathrm{M})\end{array}$ & $\begin{array}{l}\text { NAA } \\
(\mathrm{mg} / \mathrm{L})\end{array}$ & $\begin{array}{l}\text { B5 vitamins } \\
(\mathrm{mg} / \mathrm{L})^{\mathrm{c}}\end{array}$ \\
\hline IM & 4.3 & 30 & - & - & - & - & - & - & - & - \\
\hline MICE1 & 4.3 & 30 & - & - & - & 0.25 & - & - & - & - \\
\hline MICE2 & 4.3 & 30 & - & - & - & 0.5 & - & - & - & - \\
\hline MICE3 & 4.3 & 30 & - & - & - & 1 & - & - & - & - \\
\hline MRV1 & 4.3 & 30 & - & 5 & - & - & 1 & 50 & - & - \\
\hline MRV2 & 4.3 & 30 & - & 5 & - & - & 1 & - & - & - \\
\hline MEEV1 & - & 30 & 3.2 & - & - & - & - & - & 0.5 & 1 \\
\hline MEEV2 & 1.6 & 30 & - & 5 & - & - & - & - & - & - \\
\hline MEEV3 & 2.15 & 30 & - & - & - & - & - & - & - & - \\
\hline MM1 & 4.3 & 30 & - & - & 20 & - & - & - & - & - \\
\hline MM2 & 4.3 & 30 & - & - & 30 & - & - & - & - & - \\
\hline MM3 & 4.3 & 30 & - & - & 50 & - & - & - & - & - \\
\hline MM4 & 4.3 & 30 & - & 5 & 20 & - & - & - & - & - \\
\hline MM5 & 4.3 & 30 & - & 5 & 30 & - & - & - & - & - \\
\hline MM6 & 4.3 & 30 & - & 5 & 50 & - & - & - & - & - \\
\hline
\end{tabular}

${ }^{a}$ Murashige and Skoog (1962)

b Schenk and Hildebrandt (1972)

c Gamborg et al. (1968)

Q4188 x JS-83 involved five plates and was repeated three times (comprising a total of 15 plates).

The mature embryo-based regeneration protocol was based on protocols reported by Bovo and Mroginski (1989) and Grando et al. (2002), with modifications. Sterilized Q4117 seeds were placed in sterile distilled water for a period of $1-$ $24 \mathrm{~h}$ to soften the surface and facilitate embryo isolation. The seeds were scrutinized with a magnifying glass, and embryos were isolated with the help of a scalpel and tweezers. To evaluate the effect of the different PGRs and their concentrations, embryos were cultured in different media (MM5, MICE1, MICE2, and MICE3) to induce callus development (Table 1). Ten to twelve embryos were placed on each of four plates. One to eight experiments were carried out, depending on the media used. The embryos were placed on the plates always with the scutellum-side facing up. They were incubated in a chamber at $28^{\circ} \mathrm{C}$ with a photoperiod of $16-\mathrm{h}$ light/d.

The methodology used to produce calli from meristems was based on the protocol reported by Bajaj et al. (2006), with modifications. Briefly, mature seeds originating from Q4117 were incubated at $28^{\circ} \mathrm{C}$ for $48 \mathrm{~h}$. Finally, the seeds were washed three times with sterile distilled water and blotted dry on sterile filter paper. Twenty-five seeds were placed in each Petri dish (a total of 30 plates) containing IM media (Table 1) and maintained in the dark at $28^{\circ} \mathrm{C}$ for approximately $7 \mathrm{~d}$. Those plates showing germinated seeds were exposed to light for $2 \mathrm{~d}$ with a photoperiod of 16-h light/d.
Meristematic regions from approximately $1 \mathrm{~cm}$ just above the mesocotyl region were excised. Cuttings were divided longitudinally into two pieces, placed face down on different callus induction media, MM1, MM2, MM3, MM4, MM5, and MM6 (Table 1), and maintained at $28^{\circ} \mathrm{C}$ in the dark.

Once compact, nodular, white-yellow calli were obtained using any of the explants (mature seeds, mature embryos, or meristem sections), fractions of about $5 \mathrm{~mm}$ were transferred to the same media every $2 \mathrm{wk}$. After $4-5 \mathrm{wk}$, sections of about $5 \mathrm{~mm}$ diameter were transferred to regeneration media (MRV1 or MRV2) to induce shoot development (Table 1). Calli were incubated at $28^{\circ} \mathrm{C}$ in a culture chamber with a photoperiod of 16-h light/d, or in the dark. Calli with shoots longer than $5 \mathrm{~cm}$ were then transferred to flasks containing rooting medium (MEEV1 or MEEV2) and incubated at $28^{\circ} \mathrm{C}$ in a culture chamber with a photoperiod of 16-h light/d (Table 1). Data collection was performed weekly along every step of the procedure.

Seedlings showing root development were washed with distilled water to eliminate the remnants of the culture media, transferred to pots with a 1:1 soil/vermiculite mix, maintained for $1 \mathrm{wk}$ in high-humidity conditions in a growth chamber and placed in the glasshouse, which was set to operate at a maximum/minimum temperature of $35 / 15^{\circ} \mathrm{C}$. The KruskalWallis test was used to check the significance of the observed differential efficiency among seed batches and genotypes with a confidence interval of $95 \%$ using Statistical Procedures for 
Agricultural Research ('agricolae') package for the R software (Mendiburu 2013).

Ammonium glufosinate selection curve. Sterilized mature seeds originating from genotype Q4117 were placed on MM5 medium for $5 \mathrm{wk}$. Calli were then cut into sections of about $5 \mathrm{~mm}$ diameter and sub-cultured in the same medium with ammonium glufosinate as a selective agent at different concentrations $(0.5,1.0$, or $2.0 \mathrm{mg} / \mathrm{L})$. Ammonium glufosinate solutions were sterilized by filtration with $0.2 \mu \mathrm{m}$ Millipore filters and added to the temperate autoclaved media. After a period of $2 \mathrm{wk}$, calli were transferred to MRV1 medium with or without the addition of the selective agent. Then, they were divided into two groups, one of which was subjected to regeneration in the presence of the selective agent and the other in the absence of it. Selection conditions were the same as those applied in the first sub-culture. After $6 \mathrm{wk}$, calli subjected to selection that presented good shoot development (longer than $2 \mathrm{~cm}$ ) were transferred to MEEV1 medium with or without the selection agent, but calli originating from unselected sub-cultures were maintained without selection. Regeneration controls consisted of calli treated with the same protocol but without addition of the selection agent. All calli were sub-cultured every $10 \mathrm{~d}$ to maintain constant selective agent concentrations. The number of calli with shoots or shoots and roots was analyzed for each of the selective conditions and referred to as the initial number of calli. Results were compared to determine the best selection conditions using the Kruskal-Wallis test using the agricolae package for the R software (Mendiburu 2013).

Transient reporter gene expression assay. We developed a protocol based on previous reports by Smith et al. (2002), Altpeter and James (2005), and Gondo et al. (2005), with modifications aimed at increasing transformation rates in our target genotypes. Sectors of 3-wk-old calli (with a $2 \mathrm{~mm}$ maximum diameter) originating from mature seeds of genotype Q4117 were used for bombardment. Prior to bombardment, 15 calli fragments were placed on sterile filter paper discs in the center of each Petri dish containing IM medium (Table 1) plus $0.4 \mathrm{M}$ sorbitol and incubated at room temperature for $4 \mathrm{~h}$. Vectors used for transient transformation were the plasmid pDP687, including two genes that regulate anthocyanin pigments synthesis under the control of the constitutive Cauliflower mosaic virus (CaMV) 35S promoter plus the first intron of an alcohol dehydrogenase gene (Ludwig et al. 1990), or the plasmid pAct1-gfbsd2, containing an enhanced green fluorescent protein gene (egfp) driven by the rice act1 promoter (Ochiai-Fukuda et al. 2006). Cells transformed with the pDP687 plasmid developed a purple pigmentation due to the generation of anthocyanin flavonoids. Cells transformed with egfp displayed a green fluorescent signal, which was detected with a fluorescence microscope (Nikon, Eclipse E200; Nikon, Surrey, UK). Plasmids used for transformation were precipitated on tungsten particles ( $1 \mu \mathrm{m}$ diameter), as follows: $60 \mathrm{mg}$ of particles were placed in a $2 \mathrm{~mL}$ tube and washed with $1 \mathrm{~mL}$ isopropanol for $5 \mathrm{~min}$, with gentle constant shaking. They were then sonicated for $1 \mathrm{~min}$ for resuspension and centrifuged for $3 \mathrm{~min}$ at $4,000 \times \mathrm{g}$. The supernatant was discarded, and the particles were resuspended in $1 \mathrm{~mL}$ sterile distilled water with vigorous shaking to improve the washing. Subsequently, the particles were centrifuged for $3 \mathrm{~min}$ at $4,000 \times g$, and the supernatant was removed. This washing procedure was repeated twice. Finally, the particles were resuspended in $1.2 \mathrm{~mL}$ of sterile distilled water to obtain a stock $50 \mu \mathrm{g} / \mu \mathrm{L}$ suspension. This preparation was stored in a $-20^{\circ} \mathrm{C}$ freezer. Once the particles were prepared, the plasmids were precipitated on them as follows: to a $1.5 \mathrm{~mL}$ Eppendorf tube, $65 \mu \mathrm{L}$ of particle suspension, $6.5 \mu \mathrm{L}$ plasmid DNA $(1 \mu \mathrm{g} / \mu \mathrm{L})$, and $75 \mu \mathrm{L} 1 \mathrm{M} \mathrm{Ca}\left(\mathrm{NO}_{3}\right)_{2} \mathrm{pH} 10$ were added. The suspension was allowed to sediment, incubated on ice for $10 \mathrm{~min}$, and then was briefly centrifuged to discard the supernatant. Finally, the particles were washed with $100 \mu \mathrm{L} 70 \%$ $(v / v)$ isopropanol. The pellet was resuspended in $65 \mu \mathrm{L}$ isopropanol, with brief sonication to break up any clumps. The suspensions obtained using this protocol contained $50 \mu \mathrm{g}$ particles $/ \mu \mathrm{L}$ and $2 \mu \mathrm{g}$ DNA/mg particles. The same volume of sterile distilled water was used instead of plasmid DNA for controls. Fifteen microliters of the particle suspension were placed in the middle of flying membranes, previously washed with $70 \%(v / v)$ isopropanol, which were allowed to dry in a horizontal position. A Biomics gene gun (Biomics, Brasilia, Brazil) was used for these experiments. Three compressed helium-generated alternative pressures were applied: 600 , 800 , and $1,100 \mathrm{psi}$, at a microprojectile flight distance of $5 \mathrm{~cm}$. After bombardment, the calli were transferred to the same osmotic medium (IM $+0.4 \mathrm{M}$ sorbitol) for an additional hour. They were then moved to IM medium for $24 \mathrm{~h}$ and finally placed on callus induction medium. The calli were examined $48 \mathrm{~h}$ after transformation. Positive transformation events were visualized as dots on the callus surface that were purple due to the presence of anthocyanins or fluorescent due to the presence of eGFP. Data were statistically processed using the Minitab $15^{\circledR}$ Proof Version.

Stable transformation. Stable transformation experiments were performed using a protocol similar to that described above, but bombardments were carried out with equal amounts of plasmids pAct1-gfbsd2 (Ochiai-Fukuda et al. 2006) and pBS86-46 (Pact1D:cgf-s:rga2i:cgf-as:T35s/ Pubi:bar:Tnos; Thompson et al. 1987). Stable transformation was performed using a protocol similar to that described for the transient transformation. After bombardment, the calli were placed in osmotic medium (IM+0.4 M sorbitol) for an $\mathrm{h}$. Then, they were transferred to medium MICE1 containing $1 \mathrm{mg} / \mathrm{L}$ ammonium glufosinate for 4 wk (with sub-cultures every $15 \mathrm{~d}$ ). Normal calli were transferred to shoot induction 
media (MRV1) and incubated at $28^{\circ} \mathrm{C}$ in a culture chamber with a photoperiod of 16-h light/d. After $40 \mathrm{~d}$, calli with shoots longer than $5 \mathrm{~cm}$ were transferred to flasks containing rooting medium (MEEV3) and incubated at $28^{\circ} \mathrm{C}$ in a culture chamber with a photoperiod of 16-h light/d. Finally, seedlings showing good development were washed with distilled water to eliminate the remnants of the culture media, transferred to pots with a $1: 1 \mathrm{soil} /$ vermiculite mix, and maintained isolated in high humidity conditions in a growth chamber.

Molecular analysis. Plant genomic DNA was extracted from leaf tissue $(3 \mathrm{~g})$ of rooted plantlets using the protocol published by Lipp et al. (1999) for polymerase chain reaction (PCR) analyses. The presence of egfp transgene was tested in PCR assays using the primers 5'-GGGGACAGCTTTCTTG TACAAAGTGGGGATGGTGAGCAAGGGCGAGGAGC T-3' and 5'-GGGGACAACTTTGTATAAAGTTGGTTAC TTGTACAGCTCGTCCATGCC-3'. The presence of the bar gene was determined in PCR assays using the primers 5'GAGGCACAGGGCTTCAAGAG-3' and 5'-AAACCCAC GTCATGCCAGTT-3'. PCR amplifications were carried out in $25 \mu \mathrm{L}$ final volumes containing $1 \times$ Taq polymerase reaction buffer (Promega, Madison, WI), $1.5 \mathrm{mM} \mathrm{MgCl}_{2}, 0.2 \mathrm{mM}$ dNTPs, $0.2 \mathrm{mM}$ of each primer, and $1 \mathrm{U} \mathrm{GoTaq}^{\circledR}$ polymerase (Promega). The PCR cycles consisted of an initial denaturation step of $94^{\circ} \mathrm{C}$ for $5 \mathrm{~min}$, followed by 35 cycles of $94^{\circ} \mathrm{C}$ for $30 \mathrm{~s}, 58$ and $60^{\circ} \mathrm{C}$ for $1 \mathrm{~min}$ for egfp and bar, respectively, $72^{\circ} \mathrm{C}$ for $30 \mathrm{~s}$, and a final extension of $72^{\circ} \mathrm{C}$ for $10 \mathrm{~min}$. The technique described in Ortiz et al. (1997) was used for genomic DNA blot analysis. Briefly, genomic DNA was extracted from $6 \mathrm{~g}$ of young leaves using the CTAB method (SaghaiMaroof et al. 1984). Genomic DNA (30 $\mu \mathrm{g})$ was digested with restriction enzymes (EcoRI and $P s t \mathrm{I})$, electrophoresed overnight at $25 \mathrm{~V}$ in $1 \%(\mathrm{~m} / \mathrm{v})$ agarose $(1 \times \mathrm{TAE})$ gels, and blotted onto nylon membranes (Hybond N, Amersham, Pittsburgh, PA) using $10 \times$ SSC buffer. DNA was UV-fixed with a UV transilluminator for $3 \mathrm{~min}$ and then by baking at $80^{\circ} \mathrm{C}$ for $2 \mathrm{~h}$. Probes were PCR-labeled in a $100 \mu \mathrm{L}$ reaction, containing $5 \mathrm{ng}$ of plasmid DNA, $15 \%$ glycerol, $1 \times$ Taq buffer (Promega), $1.5 \mathrm{mM} \mathrm{MgCl} 2,50 \mathrm{mM}$ of each dNTP, $0.2 \mathrm{mM}$ oligonucleotides, $5 \%$ dig-dUTP, and $1 \mathrm{U}$ of Taq polymerase (Promega). Non-radioactive hybridization and detection procedures were performed according to Boehringer-Mannheim instructions (Dig Luminescent Detection Kit; Mannheim, Germany) using CSPD as a chemiluminescent substrate. Hybridized membranes were exposed to films Hyperfilm-ECL (Amersham) for 2-12 h.

In vivo assay for tolerance to ammonium glufosinate. In order to set up an in vivo assay for the tolerance to ammonium glufosinate, the mean lethal dose $\left(\mathrm{LD}_{50}\right)$ of this selective agent was determined using the genotype Q4117. Petri dishes containing $4 \mathrm{~cm}$ sections of young leaves, and $5 \mathrm{~mL}$ of ammonium glufosinate solution were placed in a growth chamber at $28^{\circ} \mathrm{C}$ with a photoperiod of 16 -h light/d for $15 \mathrm{~d}$. The different concentrations of ammonium glufosinate applied to the leaf sections were $0.0,0.5,1.0,1.5,2.5,5.0$, and $7.5 \mathrm{mg} / \mathrm{L}$. The results were analyzed using the $d r c$ (doseresponse curve) package for the $\mathrm{R}$ software (Ritz and Streibig 2005). The effective dose (ED), at a specific 50\% response level $\left(\mathrm{ED}_{50}\right)$, can be determined through a variety of data analysis methods. In this case, we used a log-logistic model (Ritz and Streibig 2005) with two parameters (lim upper $=1$ and lim lower $=0$ ) given by the following equation:

$Y=1 / 1+\exp [b(\log x-\log e)]$

where $e$ is the $\mathrm{ED}_{50}$ and $b$ denotes the relative slope around $e$. An F-test for lack of fit was done to confirm the statistical model fit. The variable reported was leaf necrosis after $2 \mathrm{wk}$ of treatment. Putative transgenic and control plants were tested for in vivo tolerance to ammonium glufosinate using the minimal lethal dose as described above. Kruskal-Wallis test was done using the agricolae package for the $\mathrm{R}$ software (Mendiburu 2013).

\section{Results}

Plant regeneration. We designed alternative protocols based on the information reported by Grando et al. (2002) and Gondo et al. (2005). A total of 2,811 mature seeds originating from Q4117 (apomictic) and 279 mature seeds from the cross Q4188 (sexual) $\times$ JS- 83 (sexual) were successfully processed. A lower number of seeds originating from the sexual genotype Q4188 was due to the limited availability of seeds. On average, the seed set of this genotype in cross-pollination was only about $27 \%$ (Acuña et al. 2007). The procedure used to sterilize the seeds was highly effective, since contamination was low (2.3\%). After 5$7 \mathrm{~d}$ of culture in MM5 medium, tiny white sprouts were observed emerging from the seeds (Fig. 1a). Formation of callus was observed in the central region of the sprouts. Approximately $4 \mathrm{wk}$ later, they had already reached $15 \mathrm{~mm}$ in size and turned yellow-brown (Fig. 1c-d). The results related to callus formation from mature seeds have been summarized in Table 2.

The calli originating from genotype Q4117 were cultured on two different shoot regeneration media (MRV1 and MRV2) differing in $\mathrm{CuSO}_{4}$ content, in two different incubation conditions (darkness or a photoperiod of 16-h light/d). The calli cultured on MRV1 in the dark underwent considerable growth; regeneration started 2-3 wk after incubation, and several shoots were obtained from the same callus. When transferred to MEEV1 medium, most shoots turned green (Fig. 1e). Better results were obtained by combining MRV1 

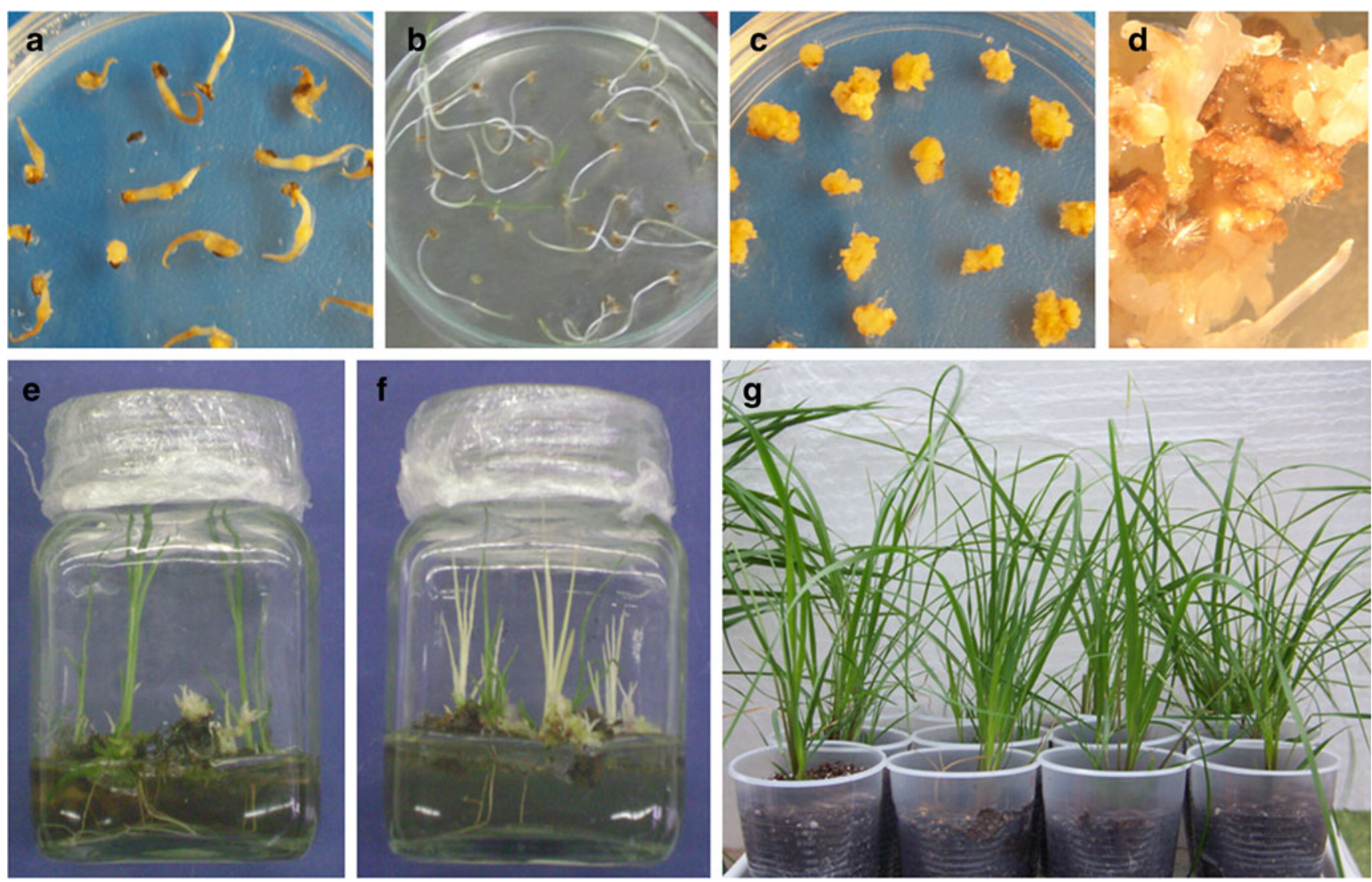

Figure 1. Plant regeneration from different explants of bahiagrass. (a) Brownish swollen sprouts and early calli formation. (b) Meristem sections cultured on MM2 medium containing $30 \mu \mathrm{M}$ dicamba and $5 \mu \mathrm{M}$ BA for $25 \mathrm{~d}$. $(c, d)$ Callus produced from a seed explant $4-5 \mathrm{wk}$ after

medium and incubation with a photoperiod of 16-h light/d. Shoots were observed emerging from calli after 3-5 wk, most of which were green, but some ( 6 out of a total of 43 shoots $=$ $14.3 \%$; Table 2) were albino (Fig. 1f). When calli were incubated in MRV2 medium, no regeneration was observed in any of the illumination conditions. Since the number of available seeds originating from sexual genotypes Q4188 $\times$ JS- 83 was low, only the best combination for the apomictic seeds was assayed (MRV1 and incubation with a photoperiod of 16-h light/d). Calli originating from Q4188 $\times$ JS- 83 showed a similar behavior to those originating from Q4117, but the process was faster (emerging shoots were observed after $2 \mathrm{wk}$ ).

After incubation in shoot regeneration medium, calli with shoots were transferred to rooting medium. Shoots originating from the apomictic genotype Q4117 were cultured in two different media: MEEV1 and MEEV2. After $1 \mathrm{wk}$, considerable elongation of the shoots and the onset of root formation were observed in the regions where calli were in contact with the culture medium. Seeds originating from the sexual genotype were assayed using only MEEV2 medium. After 4-6 wk, the seedlings had reached a considerable size and were able to be transferred to soil (Fig. 1g). No morphological alterations

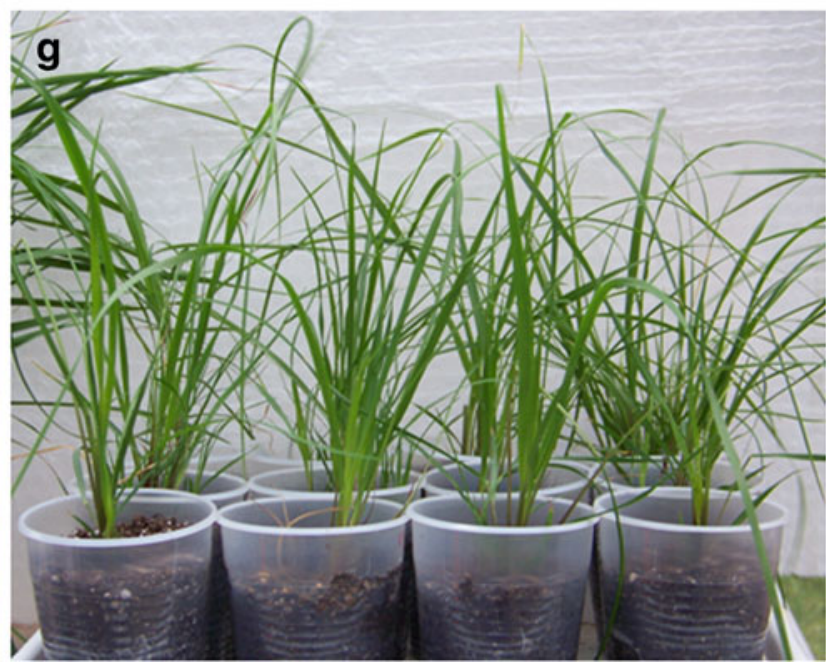

culture initiation. $(e, f)$ Regenerated green and albino shoots, respectively. (g) Regenerated plantlets with well-developed shoot and root systems growing in soil.

were observed in plants subjected to in vitro culture with respect to controls.

Calli induction data originating from the apomictic (Q4117, ten sets of seeds) and the sexual (Q4188, three sets of seeds) genotypes were compared to evaluate the effect of genotype on callus induction. A highly significant difference in behavior was detected between the genotypes. Calculations were done using percentages based on the number of seeds that produced calli. The percentage of callus induction with respect to the total seeds used was significantly higher in the sexual genotype ( $P=0.018$; Table 2$)$. Similar results have been observed for several grass species, including $P$. notatum (Smith et al. 2002; Molinari et al. 2003; Salehi and KhoshKhui 2005; Glowacka et al. 2010).

Isolated mature embryos were cultured in different media (MM5, MICE1, MICE2, and MICE3; Table 1) to evaluate the effect of PGRs and their concentrations on callus development. Callus formation was observed after 10-15 d of culture in all assayed media. Two types of calli were obtained: (1) compact, nodular, white-yellow, and potentially embryogenic and (2) friable, soft, and translucent. The type and quantity of calli varied depending on the growth regulator composition. 


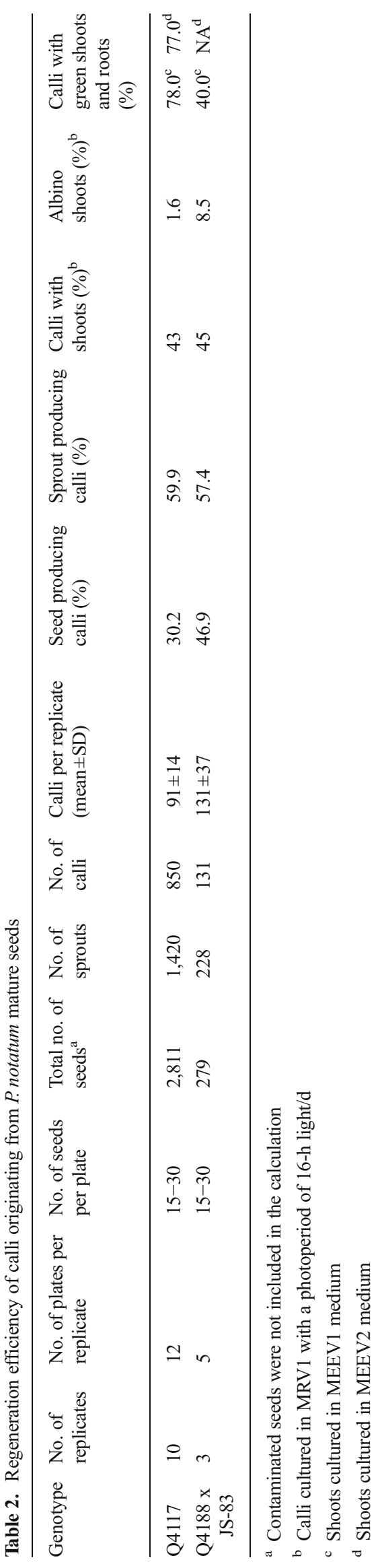

The best results were obtained in medium MICE2 with $35.2 \%$ regeneration efficiency (Table 3).

Meristematic regions of vegetative tillers derived from seedlings (Fig. 1b) were excised and spread on six different callus induction media, MM1 to MM6 (Table 1), as described in "Materials and Methods". Percentages of callus induction and shoot regeneration are shown in Fig. 2 and Table 4. After 20-25 d, calli with shoots longer than $5 \mathrm{~cm}$ were transferred to rooting medium (MEEV3). All of these calli developed roots, and those cultured on MM2, MM5, and MM6 media developed more rapidly. Statistical analyses indicated that the MM2 and MM5 media were the most suitable for callus induction from meristems $\left(P=3.18 \mathrm{e}^{-06}\right)$.

A second experiment aimed to determine the regions of the meristems that were effective for callus induction. Meristems were collected from seedlings and divided into three sections of the same size: apical, central, and basal. Callus induction results using these different explants are shown in Table 4. Calli formed on MM2 medium regenerated plants more rapidly than those formed on MM5. Regeneration was observed only from calli originating from the central meristematic sections. Regenerated lines originating on MM2 were maintained indefinitely in IM medium and were used to produce secondgeneration meristems to re-initiate an in vitro culture cycle.

Analysis of sensibility to ammonium glufosinate. The effect of ammonium glufosinate on the regeneration capacity of $P$. notatum explants was analyzed using mature seeds from genotype Q4117. An analysis of sensibility was performed according to the protocol described in "Materials and Methods". Shoots and roots were produced only when selection was applied during the calli sub-culture but not during regeneration. Based on the frequencies of regenerated plants over the total calli subjected to selection, the best selective pressure was $1.0 \mathrm{mg} / \mathrm{L}$ ammonium glufosinate. This concentration of selective agent both increased the possibility of recovering transgenic plants and minimized the quantity of plants that escaped selection (escapes). These results validated the use of ammonium glufosinate as a robust and effective selection method.

Gene delivery. Three-week-old calli originating from mature seeds of genotype Q4117 were used for bombardment. The vectors used for transient reporter gene expression assay were the plasmids pDP687 (Ludwig et al. 1990) and pAct1-gfbsd2 (Ochiai-Fukuda et al. 2006). A total of 140 calli (ten calli per plate, 14 plates) were bombarded once using three alternative compressed helium-generated alternative pressures $(600,800$, and 1,100 psi), at a microprojectile flight distance of $5 \mathrm{~cm}$. The highest pressure rendered the best results (145 transformed cells per plate). The transient reporter gene expression assay results are summarized in Table 5. After bombardment, calli were subjected to in vitro culture procedures to evaluate their 
MANCINI ET AL.

Table 3. Regeneration efficiency of calli originating from P. notatum mature embryos

\begin{tabular}{|c|c|c|c|c|c|c|c|c|c|c|c|}
\hline Medium & $\begin{array}{l}\text { No. of } \\
\text { replicates }\end{array}$ & $\begin{array}{l}\text { No. of } \\
\text { plate per } \\
\text { replicate }\end{array}$ & $\begin{array}{l}\text { No. of } \\
\text { embryos } \\
\text { per plate }\end{array}$ & $\begin{array}{l}\text { Total } \\
\text { no. of } \\
\text { embryos }\end{array}$ & $\begin{array}{l}\text { No. } \\
\text { of } \\
\text { calli }\end{array}$ & $\begin{array}{l}\text { Calli per } \\
\text { replicate } \\
(\text { mean } \pm S D)\end{array}$ & $\begin{array}{l}\text { Calli with } \\
\text { green shoots } \\
(\text { mean } \pm \text { SD) }\end{array}$ & $\begin{array}{l}\text { Calli with } \\
\text { green } \\
\text { shoots }(\%)\end{array}$ & $\begin{array}{l}\text { Calli with } \\
\text { albino shoots } \\
(\text { mean } \pm \text { SD) }\end{array}$ & $\begin{array}{l}\text { Calli with } \\
\text { albino } \\
\text { shoots (\%) }\end{array}$ & $\begin{array}{l}\text { Calli with } \\
\text { shoots and } \\
\text { roots }(\%)\end{array}$ \\
\hline MICE1 & 4 & 4 & 12 & 192 & 220 & $50.0 \pm 3.4$ & $8.6+1.4$ & 66.0 & $1.4 \pm 1.9$ & 17.3 & 9.1 \\
\hline MICE2 & 5 & 4 & $10-12$ & 228 & 190 & $32.0 \pm 8.4$ & $8.6+1.4$ & 70.1 & $0.4 \pm 0.6$ & 5.0 & 35.2 \\
\hline MICE3 & 8 & 4 & $10-12$ & 378 & 115 & $15.0 \pm 5.3$ & $5.7+2.7$ & 35.0 & $1.3 \pm 2.2$ & 16.0 & 12.4 \\
\hline MM5 & 1 & 4 & 12 & 48 & 50 & $50.0 \pm 0.0$ & $8.0+2.2$ & 36.2 & 0.0 & 0.0 & 9.0 \\
\hline
\end{tabular}

regeneration capacity. Their behavior in regeneration media (MRV1 and MEEV1) was similar to that observed for nontransformed calli.

Stable transformation of genotype Q4117 was performed on calli produced using the optimized protocol described for mature seeds, followed by post-bombardment selection with $1.0 \mathrm{mg} / \mathrm{L}$ ammonium glufosinate. Six experiments involving ten plaques containing ten calli each (600 calli in total) were carried out (Table 5). Calli were bombarded with equal amounts of the plasmids pAct1-gfbsd2 (Ochiai-Fukuda et al. 2006) and pBS86-46 (Pact1D:cgf-s:rga2i:cgf-as:T35s/ Pubi:bar:Tnos; Thompson et al. 1987), in order to achieve co-transformation (Fig. 3a-i).

Seventy-five putative transgenic plants recovered from the selection step were rusticated. A set of 42 plants was selected at random to check for the presence of the transgenes. Bar and/or egfp genes were detected by PCR in 27 plants $(64.2 \%$ transformation efficiency), with 22 plants $(52.3 \%)$ and 16 plants $(38.0 \%)$ of the transgenic plants containing egfp and bar, respectively. Eleven of the 27 transgenic plants contained both transgenes, resulting in a $40.7 \%$ co-transformation frequency (Fig. $3 k, l$ ). Genomic DNA blot analysis was undertaken for four plants (Fig. $3 m$ ). The egfp transgene was stably expressed in all main organs including leaves, stems, and roots. Fluorescence was detected in meristematic tissues, like root tips. $E g f p$ expression was also observed in ovaries and pollen grains (Fig. $3 n, p$ ). The transgenic plants were phenotypically normal and able to produce seeds.

In vivo assay for tolerance to ammonium glufosinate. An ED is defined as the dose of an agent that produces a specific effect in a defined fraction of the individuals under analysis. The "mean effective dose" $\left(\mathrm{ED}_{50}\right)$ is the dose that produces a quantal effect in $50 \%$ of the individuals. The $\mathrm{ED}_{50}$ is commonly used as a measure of reasonable expectance of a drug effect. In vitro assays with different concentration of ammonium glufosinate showed that the estimated parameters were $b=-1.76644$ and $e=0.72 \pm 0.10 \mathrm{mg} / \mathrm{L}$. A goodness-of-fit test corroborated that the data fitted to the selected model ( $P$ value $=0.7998$ ). Accordingly, $1.0 \mathrm{mg} / \mathrm{L}$ was the closest concentration to the $\mathrm{ED}_{50}(0.7 \mathrm{mg} / \mathrm{L})$ determined by the model, we used this concentration to compare the experimental plants versus wild type. Assays were carried out on plants T-51 (egfp+, bar-), T-57 (egfp+, bar-), T-29 (egfp,$+ b a r+)$, and T-65 (egfp $\left.{ }^{+}, b a r+\right)$. The results showed that plants T-29 and T-65 were significantly resistant to the ammonium glufosinate treatment, whereas plants T-51 and T-57 behaved as the wild type (Fig. 3j).
Figure 2. Percentages of calli and shoot regeneration obtained in six different media. Data are presented as mean \pm standard deviation $(n=7-5)$. Means sharing different letters denote statistically significant differences at $P<0.05$.

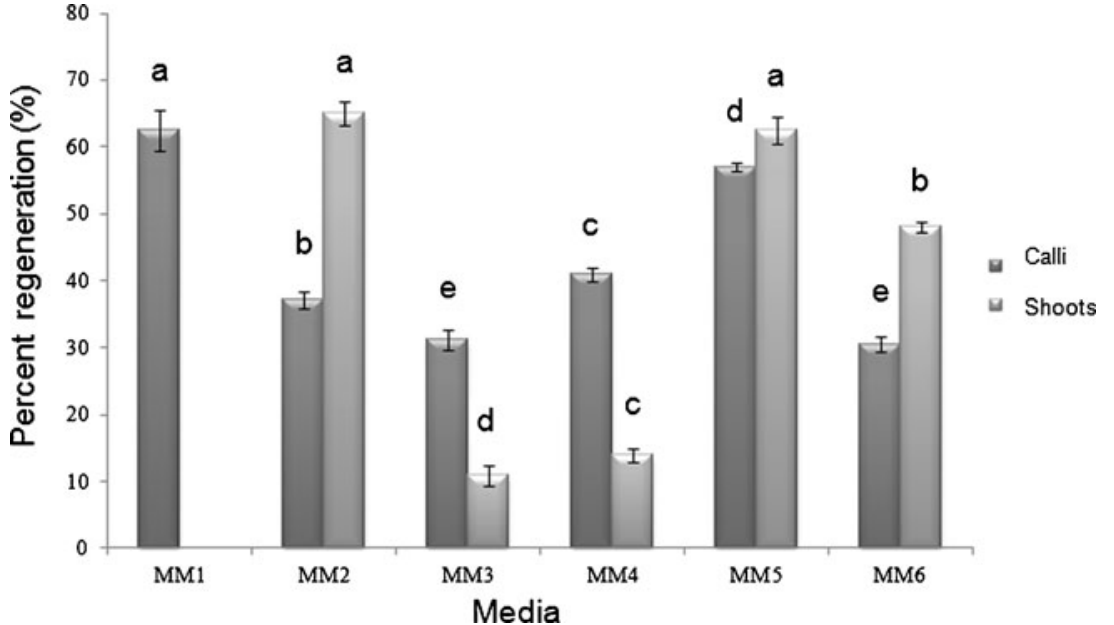


Table 4. Regeneration efficiency of calli originating from shoot meristem sections

\begin{tabular}{|c|c|c|c|c|c|c|c|c|c|}
\hline \multirow[t]{2}{*}{ Media } & \multirow{2}{*}{$\begin{array}{l}\text { No. of } \\
\text { replicates }\end{array}$} & \multirow{2}{*}{$\begin{array}{l}\text { No. of plates per } \\
\text { replicate }\end{array}$} & \multirow{2}{*}{$\begin{array}{l}\text { No. of meristems per } \\
\text { plate }\end{array}$} & \multirow{2}{*}{$\begin{array}{l}\text { Total no. of } \\
\text { meristems }\end{array}$} & \multicolumn{4}{|c|}{ Calli induction (\%) } & \multirow{2}{*}{$\begin{array}{l}\text { Shoot } \\
\text { regeneration (\%) }\end{array}$} \\
\hline & & & & & $\begin{array}{l}\text { Basal } \\
\text { section }\end{array}$ & $\begin{array}{l}\text { Central } \\
\text { section }\end{array}$ & $\begin{array}{l}\text { Apical } \\
\text { section }\end{array}$ & Total & \\
\hline MM2 & 2 & 7 & 10 & 70 & 12.8 & 37.1 & 7.8 & 57.8 & 38.3 \\
\hline MM5 & 2 & 7 & 11 & 80 & 5.0 & 13.1 & 0.6 & 18.7 & 10.0 \\
\hline
\end{tabular}

\section{Discussion}

In this work, we report the production of morphologically normal transgenic plants of the apomictic, tetraploid bahiagrass (genotype Q4117) after particle bombardment using an efficient regeneration system. The in vitro culture and plant transformation protocols used here were adapted from previous works published by Bovo and Mroginski (1989), Grando et al. (2002), Smith et al. (2002), and Gondo et al. (2005).

Success rate in the selection of putative transformed plants is mainly dependent upon the dose rate of selective agents. Their concentrations need to be carefully chosen to avoid either being too low and thereby allowing undesirable numbers of escapes to develop, or too high so that transformed plants expressing moderated levels of resistance are lost (Ijaz et al. 2012). It is a well-known fact that sensitivity to selective agents shows high dependence against genotype in monocots (Ijaz et al. 2012). Here, a P. notatum genotype that had not been transformed previously (Q4117) was tested using ammonium glufosinate. Selection curves indicated that a dose of $1.0 \mathrm{mg} / \mathrm{L}$ of ammonium glufosinate (accepting around $10 \%$ of escapes in the transformation experiments) should be used in order to detect even those events with low transgene expression, with a minimal number of escapes. Smith et al. (2002) used a higher optimum glufosinate dose $(3.0 \mathrm{mg} / \mathrm{L})$ for their $P$. notatum transformation experiments, probably due to the use of another target genotype in combination with the selection of a different threshold for tolerance of escapes. However, both transgenic plants (with bar) and non-transgenic plants (without bar) developed strong and stable resistance to ammonium glufosinate during selection (only 32 transgenic plants were identified from 674 glufosinate-resistant plants; transgenic plants recovery among selected plants $=4.7 \%$; Smith et al. 2002). A wide emergence of stable resistance to glufosinate and the consequent reduction of the selection efficiency were not observed for the P. notatum genotype used here (Q4117). In our experiments, 16 transgenic plants containing bar were identified among 42 total selected plants (transgenic plants recovery among selected plants $=38 \%$ ).

A new meristem-based in vitro culture procedure adapted from Bajaj et al. (2006) was introduced, which can be implemented to increase somaclonal variation, a desirable goal pursued in breeding strategies for clonally reproducing grasses. Another advantage of this protocol is that it demands a shorter period of tissue culture. This feature has been previously emphasized in other monocot transformation reports (Altpeter et al. 1996; Zhang et al. 2003; Gao et al. 2006).

Twenty-seven independent transgenic lines were regenerated following biolistic gene transfer of 600 calli. The transformation efficiency $(8.0 \%)$ calculated based on the bombarded calli was higher than the values 2.2\% (Gondo et al. 2005), 1.5-4.0\% (Altpeter and James 2005), 1.3\% (Agharkar et al. 2007), and 1.6\% (James et al. 2008) reported for bahiagrass. However, the efficiency of our system was lower than the $10 \%$ showed for P. notatum cv. 'Argentine' (Sandhu et al. 2007; Sandhu and Altpeter 2008). Genotypic differences and alterations in tissue culture and selection protocols may have contributed to this discrepancy.

Co-transformation allows multiple gene transfer to plants. This strategy is necessary for stacking of transgenes, the expression of different polypeptides forming a multimeric

Table 5. Gene delivery

\begin{tabular}{|c|c|c|c|c|c|c|c|}
\hline Plasmid & No. of replicates & No. of bombarded calli & Pressure (psi) & $\begin{array}{l}\text { Transformed cells/plate } \\
(\text { mean } \pm \text { SD })\end{array}$ & $\operatorname{egfp}(+)^{\mathrm{a}}$ & $\operatorname{bar}(+)^{\mathrm{a}}$ & egfp/bar $(+)^{\mathrm{a}}$ \\
\hline pDP687 & 3 & 30 & 600 & $122 \pm 45$ & - & - & - \\
\hline pDP687 & 4 & 40 & 800 & $86 \pm 23$ & - & - & - \\
\hline pDP687 & 4 & 40 & 1,100 & $145 \pm 26$ & - & - & - \\
\hline pAct1-gfbsd2 & 3 & 30 & 800 & $83 \pm 21$ & - & - & - \\
\hline pAct1-gfbsd2/pBS86-46 & 6 & 600 & 800 & - & 11 & 5 & 11 \\
\hline
\end{tabular}

\footnotetext{
${ }^{\text {a }}$ Transgenic plants detected by PCR
} 

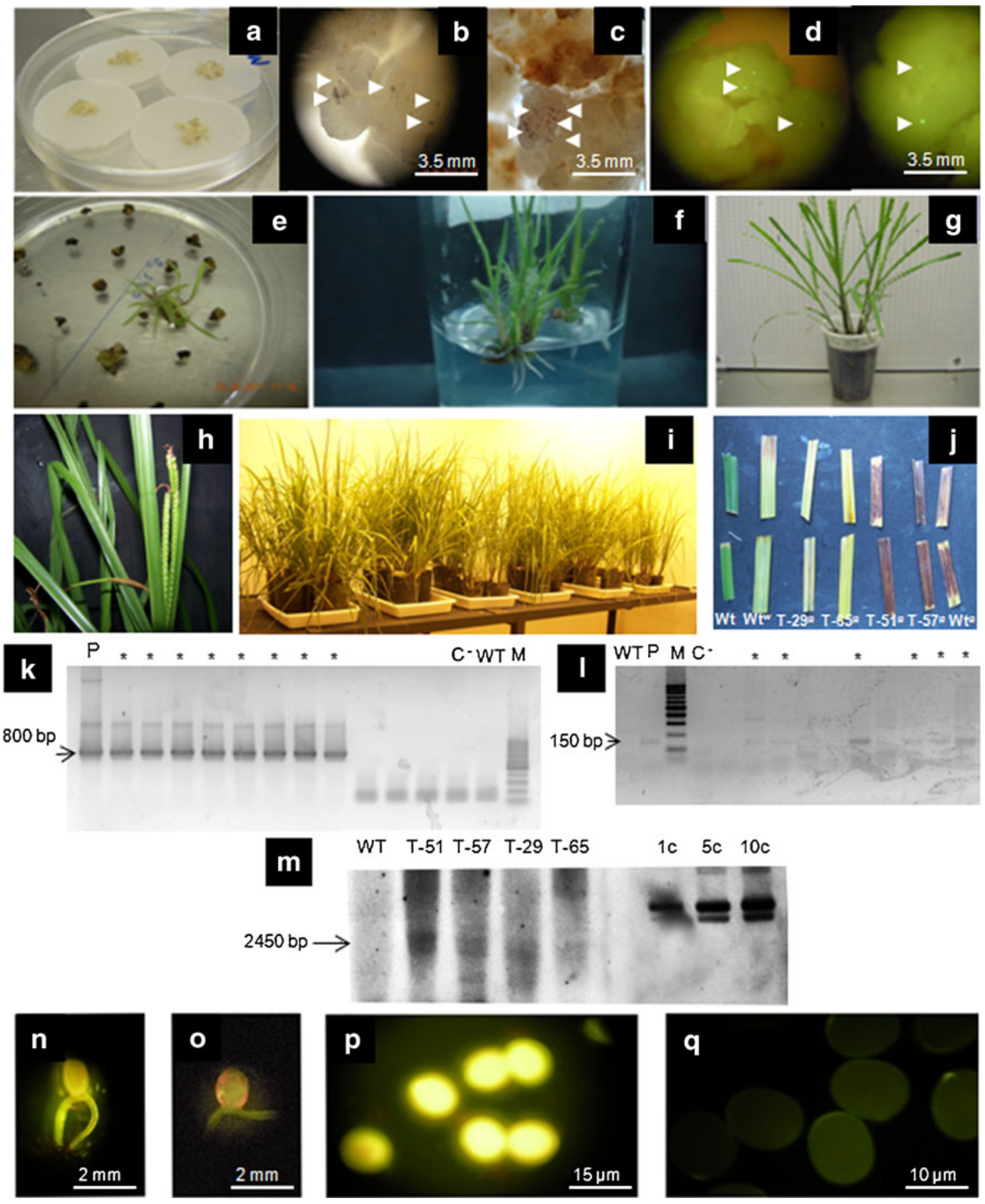

Figure 3. Transformation of tetraploid bahiagrass mediated by particle inflow gun. (a) Regenerative callus (target tissue) during osmotic treatment. (b) Bombarded calli showing tungsten particles over their surfaces (arrow heads). (c) Anthocyanin pigment accumulation $48 \mathrm{~h}$ after bombardment (arrow heads). (d) eGFP protein expression $48 \mathrm{~h}$ after bombardment (arrow heads). (e) Bialaphos-resistant shoots on medium containing $1.0 \mathrm{mg} / \mathrm{L}$ ammonium glufosinate. ( $f$ ) Bialaphos-resistant shoots on MEEV3 medium developing a root system. $(g)$ Transgenic plantlets in pots with a $1: 1$ soil/vermiculite mix. (h) Transgenic plants flowering. (i) Transgenic plants placed in a growth chamber. ( $j$ ) Evaluation of resistance to ammonium glufosinate in wild-type and transgenic plants. $W t$, wild type without treatment; $W t^{w}$, wild type using water as treatment; $T-29^{g}$ and $T-65^{g}$, transgenic plants resistant to ammonium glufosinate treated with ammonium glufosinate; $T-51^{g}$ and $T-57^{g}$, non-transgenic plants for the bar gene; and $W t^{g}$, wild-type treated with ammonium glufosinate. $(k, l)$ PCR amplification of the egfp and bar genes. Expected PCR product sizes were $800 \mathrm{bp}$ and $150 \mathrm{bp}$, respectively (arrows) $P$, plasmid as template; $C^{-}$, negative control; $W T$, genomic DNA of wild type plant as template; and $M$, molecular markers $100 \mathrm{bp}$ ). Lanes marked with (asterisk) and without marks indicate transformed plants and non-transformed plants, respectively. $(m)$ Southern blot analysis of genomic DNA using the egfp gene as probe. WT, wild-type; $T-51$, $T-57, T-65$, and $T-29$, transgenic plants; $1 c, 5 c$, and $10 c$, positive plasmid control corresponding to 1,5 , and 10 copies, respectively. (n) Detection of eGFP in reproductive tissue (ovary). (o) Wild-type ovary showing no expression of eGFP. $(p)$ Transgenic pollen grains expressing eGFP. $(q)$ Wild-type pollen grains without eGFP. 
protein, the introduction of several enzymes acting in a metabolic pathway or the expression of a target protein and the enzymes required for specific types of post-translational modification (Altpeter et al. 2005). The co-transformation frequency $(40.7 \%)$ obtained using our protocol is lower than the values of 50-60\% reported by Zhao et al. (2007) and of $81 \%$ by Kumar et al. (2010). These authors adopted similar bombardment strategies employing high molar ratios of the constructs used for co-transformation, whereas we used equal amounts of the plasmids pAct1-gfbsd2 and pBS86-46. Even so, our co-transformation efficiency is acceptable for practical applications.

Marker-free transgenic plants are a desirable target for commercial use. There are several strategies to exclude selectable marker genes from transgenic plants, such as co-transformation (Kumar et al. 2010), site-specific recombination (Gleave et al. 1999), multi-auto-transformation vectors (Ebinuma et al. 1997), transposition (Goldsbrough et al. 1993), homologous recombination (Zubko et al. 2000), genetic programming (Verweire et al. 2007), and use of alternative selection markers (Erikson et al. 2004). Nevertheless, concerns about selectable marker genes have to be addressed differently in apomictic species. Our results suggest that it is possible to obtain transgenic bahiagrass in cotransformation experiments with the gene of interest but without the selectable marker: 11 transgenic plants containing only egfp were obtained from 600 calli bombarded (1.8\%). Even though the transformation frequency was low, it may provide a reliable tool for generating transgenic apomictic plants for commercial use.

In the last few years, dozens of genes differentially expressed in apomictic and sexual developmental pathways have been isolated by several research groups from genetically poorly characterized apomictic species (Rodrigues et al. 2003; Albertini et al. 2004; Cervigni et al. 2008; Laspina et al. 2008; Yamada-Akiyama et al. 2009; Polegri et al. 2010). Some of these are protein-coding genes, which facilitated the identification of orthologs in model species and the analysis of mutant genotypes to predict their function. However, a considerable number of the identified candidates correspond to non-characterized hypothetical proteins and putative retrotransposons, miRNAs, and novel RNAs. Therefore, functional analyses of these candidate genes require the generation of mutant or transformed genotypes of the apomictic species originally used to isolate those genes. Some candidates were underrepresented in the reproductive tissues of apomictic plants with respect to sexual ones. Repression or silencing of these candidates in sexual plants and activation in apomictic plants could reveal their potential roles in reproductive development. Conversely, genes naturally over-expressed in the reproductive tissues of apomictic plants with respect to sexual ones need to be artificially upregulated in sexual plants and silenced in apomictic ones to investigate their activity. Therefore, functional analyses of these genes possibly associated with apomixis require a robust method to produce transgenic plants from both sexual and apomictic tetraploid genotypes, since apomixis expression occurs only at polyploid levels.

A biolistic platform appears to be one of the best ways to obtain large sets of transformed plants to characterize genes related to apomictic development. Here, we present several alternative protocols, starting from a variety of explants, which can be used to obtain transformed plants of tetraploid $P$. notatum. Even though all tissues proved to be suitable to generate calli and regenerated plants, we selected mature seeds as the explant of choice because of the simplicity of the technique involved. However, in the absence or shortage of seeds, the meristem-based protocol assayed here could be extremely useful. Since sexual tetraploid plants are artificial and exhibit a low seed set (Acuña et al. 2007), a meristembased protocol also represents an excellent opportunity to produce transgenic plants from this particular plant material. Moreover, when the objective is to achieve somaclonal variation (for example, in breeding programs aimed at introducing variation into clonal apomictic genotypes through tissue culture), the application of a serial meristem-based in vitro culture protocol would be most convenient.

Acknowledgments Thanks are due to Prof. Camilo Quarin for donating the plant material used in this work. We also thank Prof. German Spangenberg for kindly providing the destination vector employed to construct the plasmid pSB86-46 used for the stable transformation experiments. We thank Dr. Gabriela Breccia for her valuable advice on statistical analyses. This work was supported by: Agencia Nacional de Promoción Científica y Tecnológica (ANPCyT), Ministerio de Ciencia y Tecnología, Argentina, PICT 2007-00476, PICT 2011-1269 and PME2006-03083; Consejo Nacional de Investigaciones Científicas y Técnicas (CONICET), Argentina, PIP 11220090100613; Universidad Nacional de Rosario, proyecto 19G/253. M. Mancini, N. Woitovich, M. Podio and L. Siena received fellowships from CONICET (Consejo Nacional de Investigaciones Científicas y Técnicas, Argentina). J.P.A. Ortiz, S.C. Pessino, and S.A. Felitti are career members of CONICET.

Conflict of interest The authors declare that they have no conflict of interest.

\section{References}

Acuña CA, Blount AR, Quesenberry KH, Hanna WW, Kenworthy KE (2007) Reproductive characterization of bahiagrass germplasm. Crop Sci 47:1711-1717

Agharkar M, Lomba P, Altpeter F, Zhang H, Kenworthy K, Lange T (2007) Stable expression of AtGA2ox1 in a low-input turfgrass (Paspalum notatum Flüggé) reduces bioactive gibberellin levels and improves turf quality in field conditions. Plant Biotechnol J 5: 791-801

Albertini E, Marconi G, Barcaccia G, Raggi L, Falcinelli M (2004) Isolation of candidate genes for apomixis in Poa pratensis L. Plant Mol Biol 56:879-894

Altpeter F, Vassal V, Srivastava V, Stoger E, Vassal KI (1996) Accelerated production of transgenic wheat (Triticum aestivum L.) plants. Plant Cell Rep 16:12-17 
Altpeter F, Positano M (2005) Efficient plant regeneration from mature seed derived embryogenic callus of turf-type bahiagrass (Paspalum notatum Flüggé). Int Turfgrass Soc Res J 10:479-484

Altpeter F, Baisakh N, Beachy R, Bock R, Capell T, Christou P, Daniell H, Datta K, Datta S, Dix PJ, Fauquet C, Huang N, Kohli A, Mooibroek H, Nicholson L, Nguyen TT, Nugent G, Raemakers K, Romano A, Somers DA, Stoger E, Taylor N, Visser R (2005) Particle bombardment and the genetic enhancement of crops: myths and realities. Mol Breeding 15:305-327

Altpeter F, James VA (2005) Genetic transformation of turf-type bahiagrass (Paspalum notatum Flüggé) by biolistic gene transfer. Int Turfgrass Soc Res J 10:485-489

Bajaj S, Ran Y, Phillips J, Kularajathevan G, Pal S, Cohen D, Elborough K, Puthigae S (2006) A high-throughput Agrobacterium tumefaciens-mediated transformation method for functional genomics of perennial ryegrass (Lolium perenne L.). Plant Cell Rep 25: 651-659

Bovo OA, Mroginski LA (1989) Somatic embryogenesis and plant regeneration from cultured mature and inmature embryos of Paspalum notatum (Gramineae). Plant Sci 65:217-223

Calderini O, Chang SB, de Jong H, Busti A, Paolocci F, Arcioni S, de Vries SC, Abma-Henkens MHC, Klein Lankhorst RM, Donnison IS, Pupilli F (2006) Molecular cytogenetics and DNA sequence analysis of an apomixis-linked BAC in Paspalum simplex reveal a non pericentromere location and partial microcolinearity with rice. Theor Appl Genet 112:1179-1191

Cervigni GDL, Paniego N, Díaz M, Selva JP, Zappacosta D, Zanazzi D, Landerreche I, Martelotto L, Felitti S, Pessino S, Spangenberg G, Echenique V (2008) Expressed sequence tag analysis and development of gene-associated markers in a near-isogenic plant system of Eragrostis curvula. Plant Mol Biol 67:1-10

Chen L, Miyazaki C, Kojima A, Saito A, Adachi T (1999) Isolation and characterization of a gene expressed during early embryo sac development in apomictic Guinea grass (Panicum maximun). J Plant Physiol 154:55-62

Conner JA, Goel S, Gunawan G, Cordonnier-Pratt MM, Johnson VE, Liang C, Wang H, Pratt LH, Mullet JE, Debarry J, Yang L, Bennetzen JL, Klein PE, Ozias-Akins P (2008) Sequence analysis of bacterial artificial chromosome clones from the apospory-specific genomic region of Pennisetum and Cenchrus. Plant Physiol 147: 1396-1411

Ebinuma H, Sugita K, Matsunaga E, Yamakado M (1997) Selection of marker-free transgenic plants using the isopentenyl transferase gene. Proc Natl Acad Sci U S A 94:2117-2121

Erikson O, Hertzberg M, Nasholm T (2004) A conditional marker gene allowing both positive and negative selection in plants. Nat Biotechnol 22:455-458

Gamborg OL, Miller RA, Ojima K (1968) Nutrient requirements of suspension cultures of soybean root cells. Exp Cell Res 50:151-158

Gao C, Jiang L, Folling M, Han L, Neilson KK (2006) Generation of large numbers of transgenic Kentucky bluegrass (Poa pratensis L.) plants following biolistic gene transfer. Plant Cell Rep 25:19-25

Gleave AP, Mitra DS, Mudge S, Morris BAM (1999) Selectable markerfree transgenic plants without sexual crossing: transient expression of $C r e$ recombinase and use of the conditional lethal dominant gene. Plant Mol Biol 40:223-235

Glowacka K, Jezowski S, Kaczmarek Z (2010) The effects of genotype, inflorescence developmental stage and induction medium on callus induction and plant regeneration in two Miscanthus species. Plant Cell Tissue Organ Cult 102:79-86

Goldsbrough AP, Lastrella CN, Yoder JI (1993) Transposition-mediated re-positioning and subsequent elimination of marker genes from transgenic tomatoes. Biotechnology 11:1286-1292

Gondo T, Tsuruta S, Akashi R, Kawamura O, Hoffmann F (2005) Green, herbicide-resistant plants by particle inflow gun-mediates gene transfer to diploid bahiagrass (Paspalum notatum). J Plant Physiol 162:1367-1375

Grando MF, Franklin CI, Shatters RG (2002) Optimizing embryogenic callus production and plant regeneration from 'Tifton 9' bahiagrass seed explants for genetic manipulation. Plant Cell Tiss Org Cult 71: 213-222

Guri AZ, Patel KN (1998) Compositions and methods to prevent microbial contamination of plant tissue culture media. United States Patent Number 5:750,402

Ijaz S, Anjum N, Rana IA, Khan IA (2012) Optimization of minimal inhibitory dose of selective agent (Basta) for selection of transgenics in sugarcane. Mol Breeding 3:50-56

James VA, Neibaur I, Altpeter F (2008) Stress inducible expression of DREB $1 A$ transcription factor from xeric Hordeum spontaneum $\mathrm{L}$. in turf and forage grass (Paspalum notatum Flüggé) enhance abiotic stress tolerance. Transgenic Res 17:93-104

Kumar S, Arul L, Talwar D (2010) Generation of marker-free Bt transgenic indica rice and evaluation of its yellow stem borer resistance. J Appl Genet 51:243-257

Laspina NV, Vega T, Martelotto L, Stein J, Podio M, Ortiz JP, Echenique V, Quarin C, Pessino SC (2008) Gene expression analysis at the onset of aposporous apomixis in immature inflorescences of Paspalum notatum. Plant Mol Biol 67:615-628

Leblanc O, Armstead I, Pessino SC, Ortiz JPA, Evans E, Valle CB, Hayward MD (1997) Nonradioactive mRNA fingerprinting to visualize gene expression in mature ovaries of Brachiaria hybrids derived from $B$. brizantha, an apomictic tropical forage. Plant Sci 126: $49-58$

Lipp M, Brodmann P, Pietsch K, Pauwels J, Anklam E (1999) IUPAC collaborative trial study of a method to detect genetically modified soybeans and maize in dried powder. J AOAC Int 82:923-928

Ludwig SR, Bowen B, Beach L, Wessler SR (1990) A regulatory gene as a novel visible marker for maize transformation. Science 247:249 250

Marousky FJ, West SH (1990) Somatic embryogenesis and plant regeneration from cultured mature caryopses of bahiagrass (Paspalum notatum Flugge). Plant Cell Tiss Org Cult 20:125-129

Mendiburu F (2013) Statistical procedures for agricultural research. Statistical Procedures for Agricultural Research. http://tarwi. lamolina.edu.pe/ fmendiburu. Cited 30 Jul 2013

Molinari L, Busti A, Calderini O, Arcioni S, Pupilli F (2003) Plant regeneration from callus of apomictic and sexual lines of Paspalum simplex and RFLP analysis of regenerated plants. Plant Cell Rep 21:1040-1046

Murashige S, Skoog F (1962) A revised medium for rapid growth and bioassay with tobacco tissue cultures. Physiol Plant 15:473-497

Nogler GA (1984) Gametophytic apomixis. In: Johri GM (ed) Embryology of angiosperms. Springer-Verlag, Berlin, pp 475-518

Ochiai-Fukuda T, Takahashi-Ando N, Ohsato S, Igawa T, Kadokura K, Hamamoto H, Nakasako M, Kudo T, Shibata T, Yamaguchi I, Kimura M (2006) A fluorescent antibiotic resistance marker for rapid production of transgenic rice plants. J Biotechnol 122:521527

Ortiz JPA, Pessino SC, Leblanc O, Hayward MD, Quarin CL (1997) Genetic fingerprinting for determining the mode of reproduction in Paspalum notatum, a subtropical apomictic forage grass. Theor Appl Genet 95:850-856

Podio M, Rodríguez MP, Felitti S, Stein J, Martínez EJ, Siena LA, Quarin CL, Pessino SC, Ortiz JPA (2012) Sequence characterization, in silico mapping and cytosine methylation analysis of markers linked to apospory in Paspalum notatum. Genet Mol Biol 35: $827-837$

Polegri L, Calderini O, Arcioni S, Pupilli F (2010) Specific expression of apomixis-linked alleles revealed by comparative transcriptomic analysis of sexual and apomictic Paspalum simplex Morong flowers. J Exp Bot 61:1869-1883 
Quarin CL, Urbani MH, Blount AR, Martinez EJ, Hack CM, Burton GW, Quesenberry KH (2003) Registration of Q4188 and Q4205, sexual tetraploid germplasm lines of bahiagrass. Crop Sci 43:745-746

Ritz C, Streibig JC (2005) Bioassay analyses using R. J Stat Softw 12:1-22

Rodrigues JCM, Cabral GB, Dusi DMA, de Mello LV, Rigden DJ, Carneiro VTC (2003) Identification of differentially expressed cDNA sequences in ovaries of sexual and apomictic plants of Brachiaria brizantha. Plant Mol Biol 53:745-757

Saghai-Maroof MA, Soliman K, Jorgensen RA, Allard RW (1984) Ribosomal DNA spacerlength polymorphisms in barley: mendelian inheritance, chromosomal location and population dynamics. Proc Natl Acad Sci U S A 81:8014-8018

Salehi H, Khosh-Khui M (2005) Effects of genotype and plant growth regulator on callus induction and plant regeneration in four important turfgrass genera: a comparative study. In Vitro Cell Dev BiolPant 47:157-161

Sandhu S, Altpeter F, Blount AR (2007) Apomictic bahiagrass expressing the bar gene is highly resistant to glufosinate under field conditions. Crop Sci 47:1691-1697

Sandhu S, Altpeter F (2008) Co-integration, co-expression and inheritance of unlinked minimal transgene expression cassettes in an apomictic turf and forage grass (Paspalum notatum Flüggé). Plant Cell Rep 27:1755-1765

Schenk RU, Hildebrandt AC (1972) Medium and techniques for induction and growth of monocotyledonous plant cell cultures. Can J Bot 50:199-204

Shatters RG, Wheeler RA, West SH (1994) Somatic embryogenesis and plant regeneration from callus cultures of 'Tifton 9' bahiagrass. Crop Sci 34:1378-1384

Smith RL, Grando MF, Li YY, Seib JC, Shatters RG (2002) Transformation of bahiagrass (Paspalum notatum Flüggé). Plant Cell Rep 20:1017-1021

Spillane C, Curtis MD, Grossniklaus U (2004) Apomixis technology development - virgin births in farmers' fields? Nat Biotechnol 22: $687-691$
Stein J, Pessino SC, Martínez EJ, Rodríguez MP, Siena LA, Quarin CL, Ortiz JPA (2007) A genetic map of tetraploid Paspalum notatum Flüggé (bahiagrass) based on single-dose molecular markers. Mol Breeding 20:153-156

Thompson CJ, Movva NR, Tizard R, Crameri R, Davies JE, Lauwereys M, Botterman J (1987) Characterization of the herbicide-resistance gene bar from Streptomyces hygroscopicus. EMBO J 6: 2519-2523

Verweire D, Verleven K, De Buck S, Claeys M, Angenon G (2007) Marker-free transgenic plants though genetically programmed auto-excision. Plant Physiol 145:1220-1231

Xiong X, James VA, Zhang H, Altpeter F (2009) Constitutive expression of the barley HvWRKY38 transcription factor enhances drought tolerance in turf and forage grass (Paspalum notatum Flugge). Mol Breeding 25:419-432

Yamada-Akiyama H, Akiyama Y, Ebina M, Xua Q, Tsuruta S, Yazaki J, Kishimoto N, Kikuchi S, Takahara M, Takamizo T, Sugita S, Nakagawa H (2009) Analysis of expressed sequence tags in apomictic guineagrass (Panicum maximum). J Plant Physiol 166:750761

Zhang G, Lu S, Chen TA, Funk CR, Meyer WA (2003) Transformation of triploid bermudagrass (Cynodon dactylon x C. transvaalensis cv. TifEagle) by means of biolistic bombardment. Plant Cell Rep 21: $860-864$

Zhang S, Hanna W, Ozias-Akins P (2007) Comparison of callus induction and plant regeneration from different explants in triploid and tetraploid turf-type bermudagrasses. Plant Cell Tissue Organ Cult 97:71-78

Zhao Y, Qian Q, Wang H-Z, Huang D-N (2007) Co-transformation of gene expression cassettes via particle bombardment to generate safe transgenic plant without any unwanted DNA. In Vitro Cell Dev Biol-Plant 43:328-334

Zubko E, Scutt C, Meyer P (2000) Intrachromosomal recombination between $a t t P$ regions as a tool to remove selectable marker genes from tobacco transgenes. Nat Biotechnol 18:442-445 